\title{
NEKATERE TOPOKLIMATSKE ZNAČILNOSTI RAZPOREJANJA TEMPERATURE ZRAKA IN BURJE V RAZGIBANEM RELIEFU SLOVENIJE
}

\author{
Darko Ogrin*
}

Izvleček:

UDK:551.58(497.4)

$V$ prispevku je predstavljen problem razporejanja minimalnih temperatur zraka ob anticiklonalnem vremenu in pojav inverzije v konkavnih oblikah reliefa v Sloveniji. Podrobneje so analizirane razmere $v$ Slovenski Istri, kjer so inverzije, kljub obmorski legi, zelo izrazite, in na Visokih dinarskih planotah. Tu se v nekaterih kraških kotanjah pojavlja stalna temperaturna inverzija z vegetacijskih obratom. $V$ drugem delu pa so z uporabo metode vetrovnih krošenj in terenskih meritev predstavljene nekatere topoklimatske značilnosti burje na profilu od Trnovskega gozda do morja.

Ključne besede: topoklimatologija, minimalne temperature, inverzija, termalni pas, mrazišča, vegetacijski obrat, burja, vetrovne krošnje, Slovenska Istra, Visoke dinarske planote, Slovenija,

\section{SOME TOPOCLIMATIC CHARACTERISTICS OF THE DISTRIBUTION OF AIR TEMPERATURES AND BORA IN THE AGITATED LANDFORMS OF SLOVENIA}

\begin{abstract}
:
The paper discusses a problem of distribution of minimum air temperatures in anticyclonic weather conditions and the occurence of temperature inversions in the concave landforms of Slovenia. Analysed in more detail are the conditions in Slovenian Istria where temperature inversions are very explicit in spite of the littoral location, and the conditions on the high Dinaric plateaus where permenent temperature inversion accompanied with inversion of vegetation occur in some of the karst depressions. By applying the method of windshaped trees and actual measurements some topographic characteristics of bora, studied on the profile running from the Trnovski gozd plateau to the sea, are presented in the second part.
\end{abstract}

Key words: Topoclimatology; Minimum air temperature; Temperature inversion; Thermal belt; Mrazišče; Inversion of vegetation; Bora; Wind-shaped trees; Slovenian Istria; High Dinaric plateaus; Slovenia.

* dr. doc za fizično geografijo. Oddelek za geografijo, Filozofska fakulteta. Aškerčeva 2, IOoO Ljubljana. Slovenija, E-mail: Darko.Ogrin@FF.Uni-Lj.Si 


\section{UVOD}

Podnebje Slovenije je na makro nivoju rezultat različnih podnebnih dejavnikov. Pomembna je njena lega v zmernih geografskih širinah sorazmerno blizu Atlantskega oceana in vpliva zahodne zračne cirkulacije. Veliko vlogo ima tudi položaj Slovenije na obrobju Jadranskega morja oziroma na prehodu med Sredozemljem in evrazijsko celino. Nadpovprečnega pomena so reliefni dejavniki, kjer na splošno izpostavljamo lego Slovenije na JV obrobju Alp, za lokalne in mikroklimatske razmere pa je pomembna predvsem velika reliefna razčlenjenost našega ozemlja. Na topoklimatske razmere, s tem izrazom označujemo $v$ tem prispevku modifikacijo klimatskih razmer zaradi elementov reliefa (možna je tudi njegova uporaba kot sinonim za lokalno klimo oziroma klimo manjšega območja), pa relief vpliva predvsem z višinsko strukturo, ekspozicijo in naklonom pobočij ter tipom površja, kjer je še posebej pomembna njegova konkavnost.

Rezultat naštetih dejavnikov je, da imamo v Sloveniji, kljub njenim skromnim geografskim dimenzijam, kar tri podnebne tipe z devetimi podtipi (Ogrin, 1996): gorsko, submediteransko in zmernokontinentalno podnebje. Za vse tri je značilna njihova netipičnost, če jih primerjamo s pravim gorskim (alpskim), mediteranskim ali kontinentalnim podnebjem. Ta je posledica stičnosti in prehodnosti Slovenije med štirimi veliki makroenotami Evrope: Alp, Dinarskega gorstva, Sredozemlja in Panonske kotline.

Relief vpliva in modificira vse klimatske elemente. Znano je dejstvo, da je v Sloveniji najbolj namočena alpsko-dinarska pregrada. Ta poteka $\mathrm{v}$ dinarski smeri med Snežnikom in zahodnimi Julijci in prestavlja reliefno bariero prevladujočim zahodnim in JZ zračnim masam, ki se morajo ob njej prisilno dvigovati. Zelo pomembno vplivajo na obsevanje in prejeto sončno energijo slemenitev, ekspozicija in naklon pobočij ter reliefna razčlenjenost. Glede na Gabrovčevo študijo (Gabrovec, 1996) so razlike $\mathrm{v}$ prejeti sončni energiji pri nas zaradi razgibanega reliefa, npr. med severnimi in južnimi legami, večje znotraj posameznega klimatskega tipa, kakor pa med njimi. $\mathrm{V}$ prispevku predstavljamo vpliv posameznih elementov reliefa na nekatere temperaturne in vetrovne značilnosti. V ospredju zanimanja bo študij primerov razporejanja temperatur, predvsem minimalnih, ob radiacijskem tipu vremena v konkavnih oblikah reliefa ter izpostavljenost burji v submediteranski Sloveniji. V obeh primerih se bomo osredotočili tudi na posledice $v$ naravnem in družbenem okolju, ki izvirajo iz topoklimatskih razlik. Nekatere od njih so jasno izražene in vidne, kar nam omogoča hitro terensko analizo določenih lokalnih klimatskih značilnosti, ki so lahko pomembne tudi z vidika vojaške geografije.

\section{MINIMALNE TEMPERATURE OB RADIACIJSKEM TIPU VREMENA V KONKAVNIH OBLIKAH RELIEFA}

\subsection{Inverzijska celica in termalni pas}

$Z$ radiacijskim tipom vremena označujemo vreme, ki se oblikuje v območju anticiklona. Zanj je značilno, da je v veliki meri odvisno od kratkovalovnega sevanja Sonca čez dan in dolgovalovnega terestičnega sevanja Zemlje ponoči. Takih vremenskih situacij je pri nas, glede na raziskave Petkovška (1965), nekaj manj kot 50\% primerov 
letno, največ poleti. Če je bilanca med sevanjem površja in protisevanjem atmosfere negativna, pride ponoči do temperaturne inverzije. Inverzija je pojav, ko temperatura zraka z višino v določenem sloju zraka narašča, namesto da bi padala. Radiacijska inverzija nastane, ko se tla $\mathrm{v}$ jasnih nočeh zaradi terestičnega sevanja ohladijo, posredno od njih pa tudi prizemni sloj zraka, tako da je hladnejši od višje ležečega. Najprej nastane t.i. talna inverzija, ki sega do nekaj metrov nad tlemi, s stekanjem ob pobočjih ohlajenega zraka $v$ dno depresije pa pride do oblikovanja jezera hladnega zraka. Višina jezera hladnega zraka je odvisna od višine reliefa, ki zapira depresijo, običajno pa je med 50 in $200 \mathrm{~m}$. Če se zrak ohladi pod temperaturo rosišča, nastane kot vidni pojav inverzije megla.

Ugodne reliefne pogoje za nastanek radiacijskih inverzij in jezer hladnega zraka, ki se lahko v zimskem času zadržujejo več dni skupaj, nudijo konkavne oblike reliefa vseh oblik in dimenzij. Pri nas so to kotline, doline in vse vrste kraških depresij (udornice, vrtače, uvale, kraška polja). Kot večja inverzijska območja izstopajo Ljubljanska, Celjska, Šaleška in Slovenjgraška kotlina, doline Mure, Drave in Krke, med kraškimi depresijami pa Črnomaljski ravnik, Ribniško-Kočevsko polje, Cerkniško polje in Pivka. Zelo izrazite temperaturne inverzije nastajajo v višje ležečih kraških poljih. Znane so npr. Bloke, Rakitna in zlasti Babno polje (n.v. 765 m), kjer so ob temperaturni inverziji 15. februarja 1956 izmerili dosedaj najnižjo temperaturo pri nas, $-34,5{ }^{\circ} \mathrm{C}$.

Razen konkavnega tipa reliefa, kjer se nabira težji hladnejši zrak, morajo biti za nastanek močnih temperaturnih inverzij izpolnjeni še drugi pogoji: jasna in dolga noč, ko je terestično sevanje tal in izguba energije večja od morebitnega sevanja Sonca čez dan. Ta pogoj je pri nas izpolnjen v zimski polovici leta. Malo vlage v zraku, kar pomeni minimalno protisevanje atmosfere (minimalni atmosferski efekt tople grede) in veliko izgubo sevanja $v$ vesolje. Mirno vreme, ki preprečuje turbulentno mešanje zraka in površje prekrito s snežno odejo. Sneg ima namreč velik albedo (svež sneg 70 do $90 \%$ ), kar pomeni, da zelo malo sevanja Sonca absorbira. Istočasno pa je zelo dober sevalec, zato se površje, ki je prekrito s snežno odejo, zelo ohladi.

$\mathrm{V}$ povezavi z območji večje pogostosti temperaturnih inverzij govorimo tudi o termalnem pasu. To je pas pri višinski klimatski členitvi ozemlja, ki leži nad dnom kotlin, dolin in kraških depresij, kjer nastajajo jezera hladnega zraka, in je zato toplejši od njih, prav tako je toplejši tudi od višje ležečih predelov (Gams, 1972). Gre za enega klimatsko najbolj ugodnih predelov pri nas, ki je zelo pomemben v kmetijstvu. Tu so, zlasti v subpanonski Sloveniji praktično vsi vinogradi, veliko sadovnjakov, v submediteranski Sloveniji tudi oljčniki. Na dnu kotlin in dolin, kjer prebiva okoli $3 / 4$ slovenskega prebivalstva, je podnebje manj ugodno za rastline, še posebej bolj občutljive, saj je večja nevarnost pozeb in slane, večja je tudi vlažnost zraka in zamegljenost.

$\mathrm{S}$ problemom inverzijske celice in termalnega pasu pri nas se je podrobno ukvarjal Gams (1996). S primerjavo temperaturnih podatkov postaj v dnu dolin (kotlin) in bližnjih na pobočjih je ugotovil, da imajo postaje na vzpetinah za približno $2{ }^{\circ} \mathrm{C}$ višjo minimalno in za približno $1{ }^{\circ} \mathrm{C}$ višjo povprečno temperaturo, kot enako visoko ležeče postaje, vendar s kotlinsko lego. Za Pomurje, kjer je mreža meteoroloških postaj za študij podnebnih razmer znotraj inverznega oziroma termalnega pasu še posebej ugod- 
na, je razvidno, da imajo kraji v dnu doline samo tri mesece brez slane, dobrih $150 \mathrm{~m}$ nad dolino pa je brez slane kar šest mesecev.

Poseben problem predstavlja definicija spodnje in zgornje meje termalnega pasu. V gričevnatem subpanonskem obrobju Slovenije nakazuje obe meji vinogradniški pas. Ta je praviloma med 15 do $30 \mathrm{~m}$ nad dnom dolin in sega do približno 450 do $550 \mathrm{~m}$ nadmorske višine (Gams, 1996; Žiberna, 1992). Oljke v srednjih in zgornjih delih dolin v Slovenski Istri pa nakazujejo termalni pas od 10 do $20 \mathrm{~m}$ nad dolino, do okoli 250 , redkeje $300 \mathrm{~m}$ nadmorske višine. Za obe kulturi velja, da sta vezani na prisojna pobočja.

S pomočjo povprečnih podatkov meteoroloških postaj je opredelitev termalnega pasu težja, ker je mreža postaj pri nas preredka. Glede na minimalne temperature postavlja Gams (1996) zgornjo mejo na okoli $500 \mathrm{~m}$ relativne višine, pri povprečnih temperaturah pa pri 200 do 250 m nad dnom dolin, v višjem svetu pa domnevno višje. Na zgornjo mejo termalnega pasu na okoli $500 \mathrm{~m}$ relativne višine pri povprečnih mesečnih minimalnih temperaturah kažejo tudi ugotovitve Žiberne (1999) za Bovško kotlino, medtem ko je ta meja v Ljubljanski kotlini na okoli $400 \mathrm{~m}$.

\subsection{Primeri prizemnih temperaturnih inverzij iz Slovenije}

Temperaturni obrat je glede na pogostost pojavljanja ustreznega tipa vremena in razgiban relief pri nas zelo pogost pojav. Težko pa njegove značilnosti posplošujemo, ker so razmere od primera do primera in od tipa pokrajine do tipa pokrajine različne. V nadaljevanju bo problem inverzije in njenih posledic prikazan na dveh pokrajinsko različnih primerih, na primeru Slovenske Istre in Trnovskega gozda.

\subsubsection{Inverzija v Slovenski Istri}

Reliefno podobo Slovenske Istre sestavljata dva dela, do 450 m visoka flišna Koprska brda in 450 do 500 m visoka planota Podgorskega krasa. Zaradi erozijske neodpornosti fliša so brda močno razčlenjena $v$ sistem flišnih hrbtov in vmesnih, večjih ali manjših ter globljih in plitvih dolin in grap. Monotono površje Podgorskega krasa pa razbijajo plitve, v dinarski smeri potekajoče globeli - vale (fluviokraška podolja), ki so izrazitejša na prehodu krasa $v$ flišno gričevje.

Za temperature Slovenske Istre je značilno, da se nasplošno znižujejo od obale proti višji notranjosti. Pri tem ima pomembno vlogo morje, ki je v letnem povprečju toplejše od zraka za okoli $2{ }^{\circ} \mathrm{C}$. Zaradi tega ima priobalni pas v povprečju za 2 do $3{ }^{0} \mathrm{C}$ višje temperature od flišnega gričevja in za okoli $4{ }^{0} \mathrm{C}$ višje temperature kot Podgorski kras (Ogrin, 1995). Kljub bližini morja pa je velikega pomena za temperaturno sliko Slovenske Istre tudi inverzija. Ta se pojavlja ob ustreznem tipu vremena $v$ dolinah, tudi $v$ njihovih spodnjih delih ob morju, ne glede na letni čas. Še posebej pa je izrazita v zgornjih delih dolin ter v fluviokraških podoljih.

Temperaturne razlike $v$ obalnem pasu med dolinskimi predeli in predeli na flišnih hrbtih dobro ponazarjajo podatki za meteorološki postaji Portorož - Letališče in

Portorož - Beli križ. Postaji sta delovali zaradi selitve v obdobju 1987 - 1992 istočasno. Postaja Beli križ je bila locirana na temenu flišnega hrbta, ki se konča s Piranskim polotokom, na nadmorski višini $92 \mathrm{~m}$. Postaja v Sečovljah pa leži na akumulacijski ravnici Dragonje ob robu Sečoveljskih solin na nadmorski višini $2 \mathrm{~m}$. 
Tabela 2: Temperaturni podatki za Portorož - Beli križ in Portorož - letališ̌ce za obdobje $1987-1992$

\begin{tabular}{cccc}
\hline & Beli križ $($ n.v. $92 \mathrm{~m})$ & Letališče (n.v. 2 m) \\
\hline Povprečna temperatura $\left({ }^{\circ} \mathrm{C}\right)$ & januar & 5,3 & 3,4 \\
\hline & julij & 23,5 & 22,8 \\
\hline leto & 13,8 & 13,0 \\
\hline Povp. min. temperatura $\left({ }^{\circ} \mathrm{C}\right)$ januar & 3,1 & $-0,3$ \\
\hline & julij & 19,8 & 16,7 \\
\hline & leto & 11,0 & 8,4 \\
\hline Pov. maks. temperatura $\left({ }^{\circ} \mathrm{C}\right)$ & januar & 7,7 & 8,2 \\
\hline & julij & 27,1 & 28,7 \\
\hline & leto & 16,9 & 18,5 \\
\hline Absolutna minimalna temp. & $-8,4{ }^{\circ} \mathrm{C}$ (feb. 1991) & $-10,3{ }^{\circ} \mathrm{C}$ (feb. 1991) \\
\hline Absolutna maksimalna tem. & $32,5{ }^{\circ} \mathrm{C} \mathrm{(avg.} \mathrm{1988)}$ & $34,9{ }^{\circ} \mathrm{C}$ (avg. 1990) \\
\hline Število dni s toplo nočjo* & 37 & 4 \\
\hline
\end{tabular}

*Št. dni z minimalno temperaturo pod $20^{\circ} \mathrm{C}$

Vir podatkov: Arhiv HMZ RS

Iz podatkov je razvidno, da ima 90 m višje ležeča postaja na Belem križu za $0,8{ }^{0} \mathrm{C}$ višje povprečne letne temperature kot sečoveljsko letališče. Razlika je večja $v$ zimskih mesecih, saj je povprečna januarska temperatura na letališču v Sečovljah za skoraj $2{ }^{\circ} \mathrm{C}$ nižja kot na Belem križu. Še večje so razlike pri minimalnih temperaturah, ki so ob spodnji Dragonji povprečno za okoli $2,5^{\circ} \mathrm{C}$ niže od belokrižkih. Pozimi je razlika večja, znaša okoli $3,5^{\circ} \mathrm{C}$. Da leži Sečoveljska dolina tudi poleti zelo pogosto v jezeru hladnega zraka, ki polzi proti morju, kaže tudi število dni s toplo nočjo. V Sečovljah so ostale nočne temperature nad 20 ${ }^{0} \mathrm{C}$ v povprečju le 4 krat na leto (približno tolikokrat kot v višjem zaledju), medtem, ko je bilo takih dni na Belem križu kar 37, od junija do vključno septembra teoretično vsak tretji dan. Inverzija nad Sečoveljsko dolino je v zgodnjih jutranjih urah zelo pogosto vidna $v$ obliki meglice, ki se nekaj $10 \mathrm{~m}$ nad dolino širi tudi nad notranje dele Piranskega zaliva. Temperaturne razlike med predeli Slovenske Istre, ki so pod inverzijo in tistimi, ki so izven, so večje od predstavljenih povprečij, če pogledamo posamezne situacije. V ta namen smo v obdobju poletje 1991- jesen 1993 opravljali meritve minimalnih temperatur na okoli 60 merilnih mestih, s katerimi smo pokrili vse reliefne enote Slovenske Istre. Meritve smo opravljali ob izrazitem anticiklonalnem vremenu, $v$ vseh letnih časih, uro do uro in pol pred sončnim vzhodom. Merili smo z digitalnim termometrom s sevalno zaščito, čigar senzor smo pritrdili na avto okoli $1,8 \mathrm{~m}$ nad tlemi. Meritve smo opravljali med vožnjo s konstantno hitrostjo okoli $40 \mathrm{~km} / \mathrm{h}$. Zaradi spremembe temperature $s$ časom smo izmerjene vrednosti zreducirali na začetek meritev.

Ne glede na letni čas je bila razporeditev temperatur podobna. Najnižje temperature smo namerili na Podgorskem krasu in v konkavnih oblikah reliefa, tudi neposredno ob obali. V njih se je pojavljala temperaturna inverzija, ki je bila najmočnejša v fluviokraških podoljih v notranjosti Slovenske Istre (Movraška, Smokavska, Gračiška in Sočerska vala) in v 
zgornjih delih dolin Drnice, Dragonje, Rokave in Rižane. Omenjena fluviokraška podolja ležijo razmeroma visoko (170 do $300 \mathrm{~m}$ ) in po obliki spominjajo na kraška polja, kjer so zaradi višjega roba še posebej ugodni pogoji za oblikovanje jezer hladnega zraka. Inverzna plast zraka je bila različno visoka, večinoma pa med 30 in $50 \mathrm{~m}$. Kraji izven nje so imeli od 4 do $8{ }^{\circ} \mathrm{C}$ višje temperature. Tako je bila razlika 2.1.1992 med Movraško valo, ki leži v izraziti depresiji na n.v. okoli $170 \mathrm{~m}$, kjer smo namerili $-5,1{ }^{\circ} \mathrm{C}$ in $100 \mathrm{~m}$ višje ležečo Smokvico 3,9 ${ }^{\circ}$ C. Spomladi (8.5.1992) pa med Gračiško valo (n.v. $280 \mathrm{~m}$ ) in $100 \mathrm{~m}$ višje ležečimi Butari kar $7,5^{\circ} \mathrm{C}$. V takih situacijah so veliki tudi vertikalni temperaturni gradienti. Ob že omenjeni zimski situaciji je npr. znašal med dolino Rokave in $50 \mathrm{~m}$ višje ležečimi Babiči $5,4^{0} / 100 \mathrm{~m}$.

$\mathrm{V}$ spodnjih delih dolin je bila inverzija nekoliko šibkejša. Razlika med merilnimi mesti v dolini in tistimi na flišnih hrbtih je znašala od 1 do $4{ }^{\circ} \mathrm{C}$. 2.1 .1992 smo npr. namerili v Luciji $-0,2{ }^{\circ} \mathrm{C}$ (bila je slana), na $80 \mathrm{~m}$ višji Valeti pa $3,3{ }^{\circ} \mathrm{C}$.

Najvišje temperature so imeli flišni hrbti v priobalnem in osrednjem delu gričevja do nadmorske višine okoli $300 \mathrm{~m}$. Ti so bili toplejši od val za 8,5 do $9{ }^{\circ} \mathrm{C}$. Višje gričevje, predvsem okoli Pregare, je imelo nižje temperature zaradi višje lege. Po 1 do $2{ }^{\circ} \mathrm{C}$ višjih temperaturah od svoje okolice so izstopali tudi gosto pozidani predeli obalnih mest, kjer je opazen učinek mestne klime.

Slika 1: Razporeditev minimalnih temperatur ob anticiklonalnem tipu vremena jeseni $v$ Slovenski Istri (meritve 8.11.1991; 5:10 - 7:00)

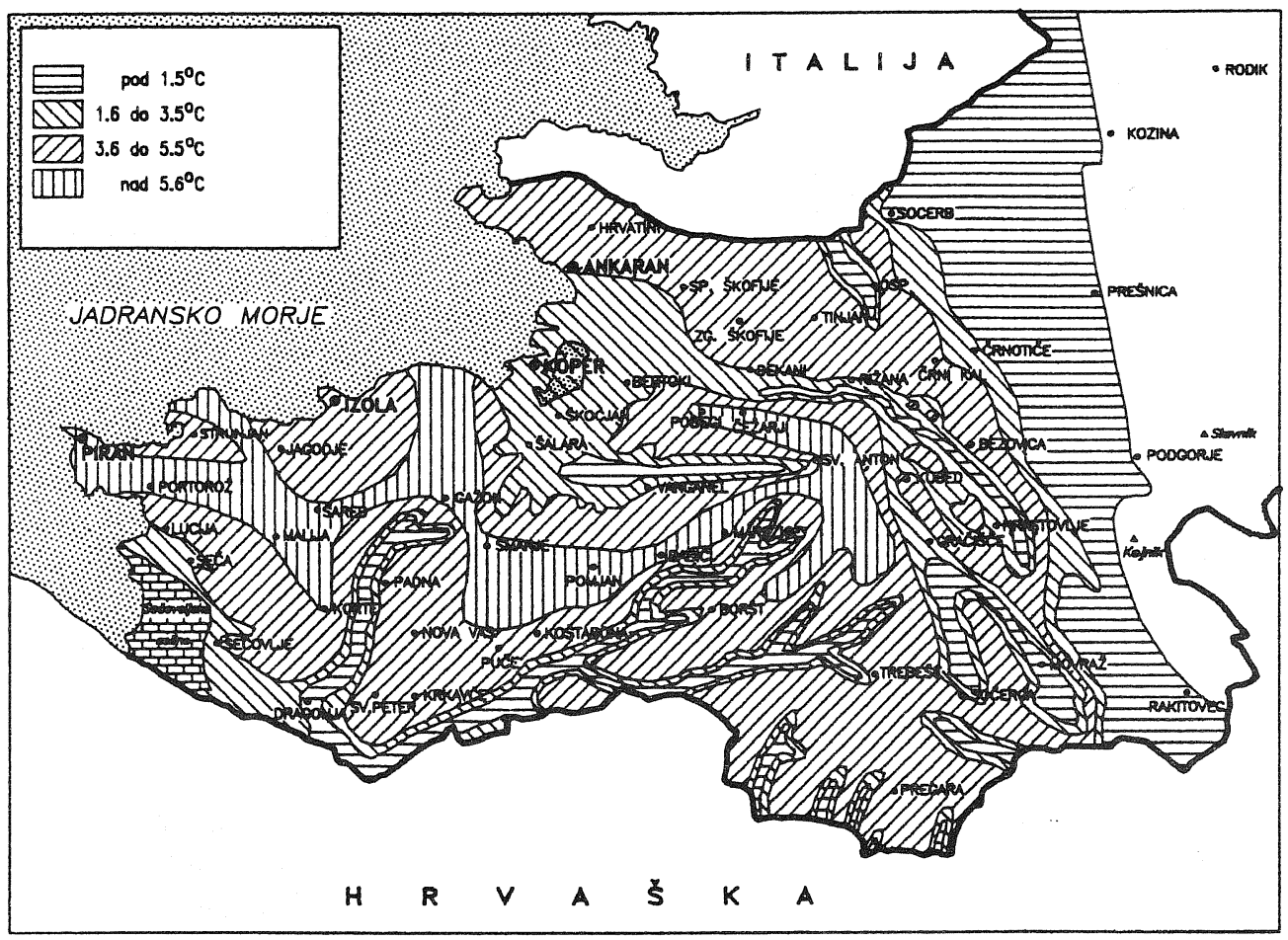


$\mathrm{Na}$ veliko pogostost inverzijskega razporejanja temperature $\mathrm{v}$ Slovenski Istri in na pomembnost razlik pri minimalnih temperaturah, ki se pojavijo med dolinskim in vzpetim reliefom, kažejo tudi spomladanske fenofaze pri nekaterih najbolj pogostih submediteranskih drevesnih vrstah (hrast puhavec, graden, mali jesen). Opazovanja in meritve vršnih poganjkov aprila in maja 1992 in 1993 so pokazala, da razvoj vegetacije v dnu zgornjih dolin in v fluviokraških podoljih zaostaja za temeni flišnih hrbtov za 7 do 10 dni (Ogrin, 1995). Ostrejše klimatske razmere v grapah povirnega dela Dragonje nakazuje tudi združba bukve in jesenske vilovine, ki tu osamljeno uspeva zaradi vlažnejših tal in hladnejše lokalne klime (Dakskobler, 1996). Ta združba se sicer v bolj strnjeni obliki pojavlja šele na prehodu submediteranskega podnebja v gorsko oziroma celinsko podnebje osrednje Slovenije.

\subsubsection{Inverzija in mrazišča na Trnovskem gozdu}

Trnovski gozd je visoka kraška planota, ki leži večinoma v nadmorski višini 800 do 1500 $m$ med dolino Idrijce na SV in Vipavsko dolino na JZ. Planota je precej uravnana, njena značilnost so velike vrtače, kraške globeli - drage (Mrzla, Mojska in Smrekova draga), suhe doline in vmesni kopasti vrhovi. Trnovski gozd ima podnebje, ki je značilno za nižji gorski svet, z veliko količino padavin. Ena od klimatskih značilnosti Trnovskega gozda in vseh planot Visokega dinarskega krasa, je pojav občasnih in stalnih temperaturnih inverzij $v$ kraških kotanjah in globelih ter z njimi povezan vegetacijski obrat oziroma pojav mrazišč. Pri mraziščih $z$ vegetacijskim obratom gre za obrnjeno razporeditev višinskih vegetacijskih pasov, kakor smo jih vajeni $\mathrm{v}$ gorah.

\section{Mrazišče Velike ledene jame v Paradani}

Velika ledena jama $v$ Paradani je primer klasičnega mrazišča s stalno temperaturno inverzijo in vegetacijskim obratom, ki je zelo zgodaj pritegnil raziskovalce. Prvi je ta pojav opisal Beck (1906), kasneje so ta fenomen raziskovali tudi Martinčič (1977), Gams in Mihevc (1978) idr. Pri tem tipu mrazišča se pri dnu (ali v jami, v katero se običajno nadaljuje) vse leto ohranjata sneg in led, ki predstavljata najpomembnejši sekundarni vir ohlajevanja zraka. Temperatura zraka pada bolj ali manj pravilno od zgornjega roba proti dnu mrazišča. Prava temperaturna inverzija pa je razvita le $v$ predelu, ki je vedno $v$ senci. Pobočja in zrak nad njimi se lahko čez dan močno segrejejo.

Mrazišče v Paradani je nastalo na nadmorski višini okoli $1100 \mathrm{~m}$, v okoli $90 \mathrm{~m}$ globoki udornici, ki se konča z ozko lijakasto vrtačo in jamo. V vhodnem delu jame se nabira sneg, ki se plazi po strmem severnem pobočju vrtače. Zaradi navpične južne stene vhoda v jamo sonce nikoli ne doseže dna, zato se sneg, ki se ščasoma preobrazi v led, tu ohranja vse leto in vzdržuje temperaturni obrat.

Posledica temperaturne inverzije in temperaturnega režima tal, za katerega je v vegetacijski dobi pomemben tudi dotok hladnega zraka skozi razpoke iz podzemlja, je vegetacijski obrat. Dotok hladnega zraka iz podzemlja in njegovo zadrževanje $v$ gruščnatih tleh je lahko celo odločilen dejavnik, ki privede do vegetacijskega obrata, kot npr. v primeru Smrekove drage na severni strani Golakov v bližini Paradane. Tu dno in nižje dele pobočij pokrivata rušje in smreka, višje dele pobočij in plato pa dinarski jelovo-bukov gozd (Martinčič, 1977).

Od vrha mrazišča Velike ledene jame v Paradani do večnega snega in ledu si sledijo naslednji vegetacijsko - floristično ekološki pasovi: pas dinarskega bukovo-jelovega gozda, pas 
smreke, pas velelistne vrbe, pas subalpskih grmičkov, pas alpskih zelišč in pas mahov (Martinčič, 1977). Pas dinarskega bukovo-jelovega gozda, ki porašča večino Trnovskega gozda, se prične kakih $30 \mathrm{~m}$ nad vhodom v jamo. Navzdol meji na pas smreke, ki pa porašča le majhne površine. Smrečje preide v pas velelistne vrbe. Ta pas predstavlja razmere, kakršne so na višini gozdne meje, kjer je velelistna vrba zelo številna. Naslednji je pas subalpskih grmičkov, kjer prevladujeta rododendron in slečnik. Iz neznanega vzroka pa ni rušja, ki je sicer najpomembnejša vrsta tega pasu. Normalno uspevajo te vrste 600 do 800 m višje. Pas subalpskih grmičkov meji navzdol na pas alpskih zelišč. Tu je mikroklima izrazito visokogorska, zato uspevajo le hladnoljubne rastline, nekatere so prave alpske, kot npr. planika in alpski repnjak. Okoli vhoda $\mathrm{v}$ jamo, $\mathrm{v}$ neposredni bližini snega in ledu, uspevajo le še mahovi. Ekstremni mikroklimatski pogoji in slaba svetloba onemogočajo uspevanje cvetnic.

\section{Slika 2: Mrazišče Velike ledene jame v Paradani (foto: D.Ogrin)}

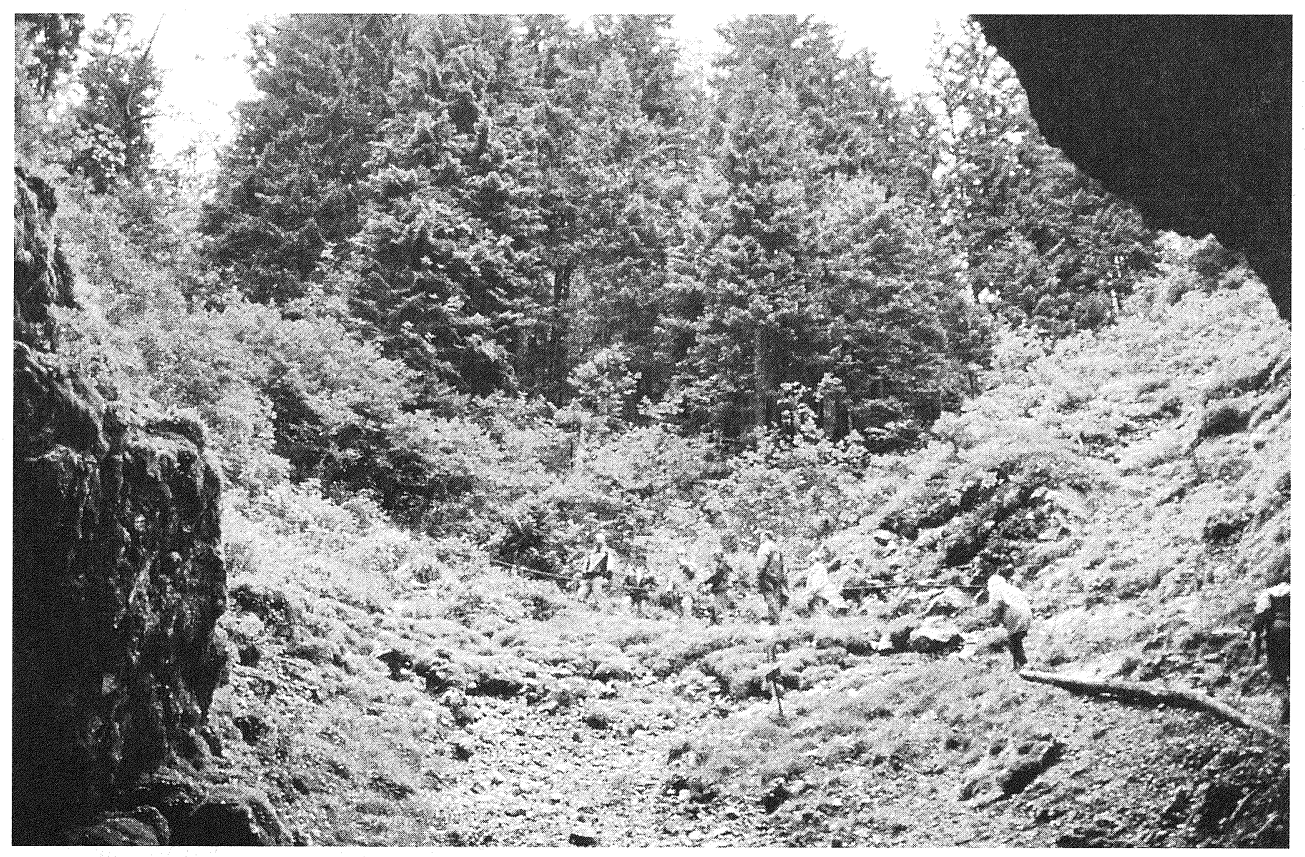

$\mathrm{V}$ območju večnega snega in ledu so temperature zraka najnižje in tudi najbolj stabilne, $\mathrm{v}$ topli polovici leta so med 1 in $3{ }^{0} \mathrm{C}$, v hladni polovici pa se spustijo pod ledišče. Višje se temperature, zlasti ob sončnem vremenu $v$ topli polovici leta, naglo dvignejo. $V$ tem primeru je inverzija razvita le v spodnjem delu vrtače do grmiščnega pasu velelistne vrbe. Tu je sončno obsevanje tal in temperatura zraka zaradi nizke in redke vegetacije najvišja, višje pa zaradi senčnosti smrekovega in mešanega gozda temperatura pada. Take razmere smo zabeležili 3.5.1994, ob 12.30, ko smo merili temperaturo zraka na višini $1,8 \mathrm{~m}$ in $5 \mathrm{~cm}$ nad tlemi (Tabela 2). Nad večnim snegom in ledom je bila temperatura $2,7{ }^{\circ} \mathrm{C}$ oziroma $2,4{ }^{0} \mathrm{C}$, v pasu alpskih zelišč 6,2 oz. $4,6{ }^{\circ} \mathrm{C}$, v pasu velelistne vrbe pa $15,2 \mathrm{oz} \cdot 15,6{ }^{\circ} \mathrm{C}$. V pasu smreke, se je spustila na $11,3{ }^{\circ} \mathrm{C}\left(11,2^{\circ} \mathrm{C}\right)$, v pasu mešanega jelovo-bukovega gozda pa na 
$10,3\left(10,1^{\circ} \mathrm{C}\right)$. Temperaturna amplituda med najtoplejšim in najhladnejšim pasom je $\mathrm{v}$ tem primeru znašala $12,5^{0}(1,8 \mathrm{~m})$ oziroma $13,2^{\circ} \mathrm{C}(5 \mathrm{~cm})$, ob toplejšem vremenu pa lahko preseže tudi $20^{\circ} \mathrm{C}$.

$\mathrm{V}$ celotnem profilu mrazišča je temperaturna inverzija razvita le ob oblačnem vremenu. Tedaj temperatura narašča od večnega snega in ledu do vrha mrazišča. 29.10.1999, ob 14.30 , smo npr. na dnu $1,8 \mathrm{~m}$ nad tlemi namerili $1,9^{\circ} \mathrm{C}$, v pasu subalpinskega grmičevja $9,2{ }^{\circ} \mathrm{C}$ in na vrhu $14,0^{\circ} \mathrm{C}$ (tabela 2 ).

Tabela 2: Temperature v mrazišču Velike ledene jame v Paradani ob jasnem in oblačnem vremenu

\begin{tabular}{|c|c|c|c|c|}
\hline \multirow{2}{*}{$\begin{array}{l}\text { Floristično-vegetacijsko } \\
\text { ekološki pasovi }\end{array}$} & \multicolumn{2}{|c|}{ Jasno, $3.5 .1994,12: 30$} & \multicolumn{2}{|c|}{ Oblačno, $29.10 .1999,14: 30$} \\
\hline & $1,8 \mathrm{~m}\left({ }^{\circ} \mathrm{C}\right)$ & $5 \mathrm{~cm}\left({ }^{\circ} \mathrm{C}\right)$ & $1,8 \mathrm{~m}\left({ }^{\circ} \mathrm{C}\right)$ & $5 \mathrm{~cm}\left({ }^{\circ} \mathrm{C}\right)$ \\
\hline Dinarski jelovo-bukov gozd & 10,3 & 10,1 & 14,0 & 13,8 \\
\hline Pas smreke & 11,3 & 11,2 & 12,9 & 12,7 \\
\hline Pas velelistne vrbe & 15,2 & 15,6 & 12,4 & 12,3 \\
\hline Pas subalpskih grmičkov & 9,9 & 8,9 & 9,2 & 9,2 \\
\hline Pas alpskih zelišč & 6,2 & 4,6 & 6,0 & 5,5 \\
\hline Pas mahov & 2,7 & 2,4 & 1,9 & 2,1 \\
\hline
\end{tabular}

\section{BURJA IN NEKATERE NJENE TOPOKLIMATSKE POSEBNOSTI}

Zaradi lege v zavetrju Alp in kotlinsko - dolinskega reliefa je za Slovenijo značilna slaba prevetrenost in velik delež brezvetrja pri tleh. Če piha veter, potem prevladujejo vetrovi iz zahodnega kvadranta, kar je posledica vpliva geografske širine oziroma lege v območju planetarnega zahodnika. Po prevetrenosti nekoliko izstopa Primorje, kjer pogosto piha burja. V Postojni npr. je po podatkih za obdobje 1961-1990 s 30\% zastopanostjo daleč najbolj pogost veter.

Burjo označujemo kot močan, sunkovit, hladen in suh veter, ki piha iz vzhodnega kvadranta, najpogosteje iz SV. Značilna je za SV obalo Jadranskega morja, v Sloveniji piha JZ in južno od Visokih dinarskih planot (Banjšice, Trnovski gozd, Nanos, Javorniki, Snežnik). Pihati začne po prehodu hladne fronte, ko se hladnejši, gostejši in težji zrak, potem ko je zapolnil nižinski svet na kontinentalni strani Visokih dinarskih planot, začne zlivati prek grebenov na primorsko stran pod tamkajšnji toplejši zrak. Burja piha v vseh letnih časih, najpogostejša pa je pozimi, ko je nad $S$ in srednjo Evropo rażvit anticiklon, nad Sredozemljem pa je območje nizkega zračnega pritiska. Piha lahko do 6 dni, najpogosteje pa dan ali dva. Za burjo je značilna sunkovitost, ki je posledica valov na zgornji meji hladnega zraka in vrtincev zaradi trenja ob pobočjih. Najmočnejša je pod visokimi grebeni, pri nas v Vipavski dolini, ko lahko posamezni sunki presegajo $50 \mathrm{~m} / \mathrm{s}(180 \mathrm{~km} / \mathrm{h})$. Zaradi svoje jakosti in pogostosti pomembno vpliva na življenje $v$ Primorju: odkriva strehe, ovira promet, podira drogove, lomi drevesa ipd.

\subsection{Ugotavljanje značilnosti burje s pomočjo vetrovnih krošenj}

Zaradi razgibanega reliefa, kjer je velikega pomena potek slemenitve, višina grebenov, reliefni skoki in oddaljenost od Visokih dinarskih planot, burja ni povsod enako pogosta in 
enako močna ter nima enotne smeri. Ena od metod, ki se uporablja pri terenskih raziskavah burje in ostalih močnejših vetrov, je kartiranje preoblikovanosti drevesnih krošenj zaradi vetra. V ta namen je Barsch (1963) izdelal lestvico deformacij, ki so jo pri študiju burje ob jadranski obali in tudi pri nas uporabili Yoshino in sodelavci (Yoshino, 1976). Lestvica ima 6 stopenj. Pri prvi stopnji je krošnja le nekoliko asimetrična v smer zavetrja, pri drugi že nekoliko bolj, pri tretji so veje na privetrni strani bistveno krajše in krošnja zelo asimetrična, pri četrti vej na privetrni strani praktično ni, deblo je še pokončno, pri peti je tudi deblo nagnjeno v smer zavetrja, pri šesti stopnji pa je veter tako pogost in tako močan, da drevo raste dobesedno po tleh. Lestvica je prirejena za listavce, za raziskavo deformacij iglavcev jo je treba nekoliko modificirati, predvsem zato, ker deblo tudi pri višji stopnji poškodovanosti dlje vztraja v pokončni rasti.

\section{Slika 3: Bukve s 4.do 5. stopnjo deformiranosti krošnje na Sinjem vrhu (foto: D.Ogrin)}

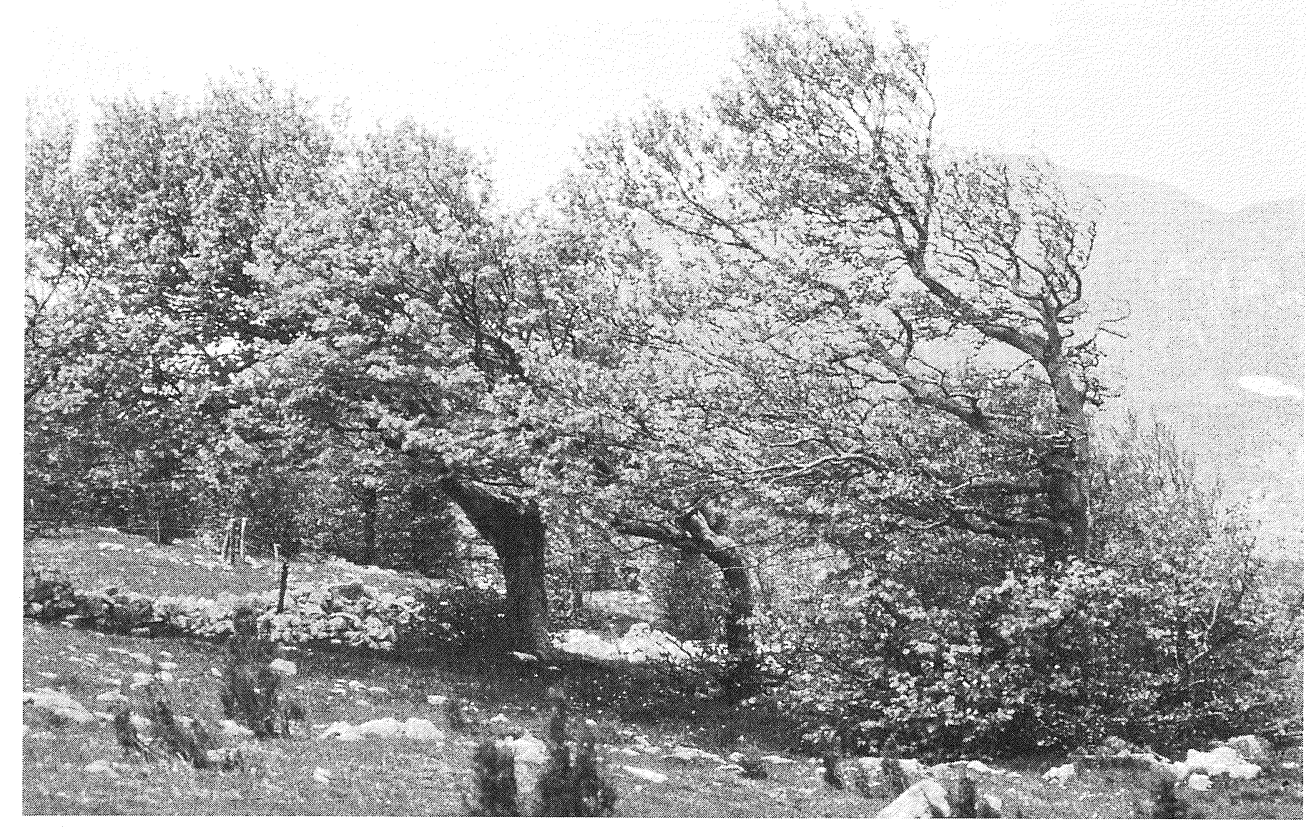

V letih 1971 in 1973 so japonski strokovnjaki, ob pomoči domačih, izvajali primerjalne terenske meritve smeri in hitrosti burje v Vipavski dolini v okolici Ajdovščine in dobljene rezultate primerjali z razmestitvijo dreves z različno stopnjo deformiranosti. Raziskava je pokazala visoko stopnjo sovpadanja. Ugotovljeno je bilo, da je območje najmočnejše burje in največje deformiranosti drevja ob vznožju Trnovskega gozda in v okolici letališča v Ajdovščini (Yoshino et al., 1976).

Po isti metodologiji je izpostavljenost burji na robni polici Trnovskega gozda (n.v. 820 do 850 m), v območju Sinjega vrha ugotavljala Kavčičeva (1996). Na raziskovalni ploskvi široki okoli $1 \mathrm{~km}$ in dolgi $2 \mathrm{~km}$ je ugotovila, da je prevladujoča smer burje sever do SV in da je burji najbolj izpostavljen pregib robne police v Vipavsko dolino in privetrna, severna in SV stran Sinjega vrha (n.v. 1002 m), ki se kot nekakšen osa- 
melec dviga nad robno uravnavo. Stopnjo poškodovanosti dreves je ocenila na 4 do 5. Ostali predeli so burji manj izpostavljeni, najmanj v dinarski smeri ležeča podolja pravokotno na njeno smer in zavetrne strani vrhov. Pri podoljih, ki potekajo približno v smeri S - J, je bilo opaziti kanaliziranje vetra, z največjimi hitrostmi kakih $10 \mathrm{~m}$ nad nivojem podolja, kjer je trenje zaradi mikroreliefa (vrtače) manjše. Za zavetrno stran Sinjega vrha je bilo ugotovljeno, da so krošnje dreves deformirane v smeri S oziroma SV, iz česar sklepamo, da prihaja pri prehodu burje čez osamelec do vetrovnega rotorja in vrtinčenja ter nastanka protismeri vetra.

Ena od značilnosti burje je, da se njena moč zmanjšuje z oddaljevanjem od Visokih dinarskih planot. $\mathrm{Z}$ uporabo Barschove lestvice oziroma s primerjavo deformiranosti drevja na najbolj izpostavljenih predelih na Sinjem vrhu in v Slovenski Istri smo skušali ugotoviti, za koliko se jakost burje na tem profilu zmanjša in kateri predeli Slovenske Istre so burji najbolj izpostavljeni.

Raziskava je pokazala, da je v Slovenski Istri burji najbolj izpostavljen Podgorski kras in nasproti njemu ležeči Tinjan, s tem, da je najbolj na udaru, podobno kot na Trnovskem gozdu, JZ rob Podgorskega krasa, čez katerega se burja preliva v Osapsko in Rižansko dolino ter Movraško valo. Tu je drevje deformirano do 3., največ 4. stopnje, torej za stopnjo do dve manj kot na Trnovskem gozdu. V notranjosti Podgorskega krasa, zlasti pod Slavniškim pogorjem, pod strukturnimi stopnjami in $\mathrm{v}$ fluviokraških podoljih, je burja manj izrazita.

Z oddaljevanjem od Podgorskega krasa proti JZ burja slabi. Drevesa so v večji meri prizadeta še v predelih nasproti Podgorskega krasa (Brda, Kubejska Varda, Lačna, Kras med Movraško in Sočersko valo) ter na Pregarski planoti, kjer smo zabeležili deformacije druge do največ tretje stopnje. Še bolj proti JZ pa smo deformacije prve do druge stopnje registrirali na temenih flišnih hrbtov med Borštom in Laborjem, med Pomjanom, Krkavčami in Padno ter med Malijskim hribom in Kaštelirjem. V ostalih predelih, zlasti nižje ležečih, deformacij nismo odkrili. Nekaj vetrovnih krošenj smo sicer zabeležili še na izpostavljenih rtih ob morju (Beli Križ, Punta v Izoli, rt Viližan), vendar so bila to umetno zasajena parkovna drevesa.

Zmanjševanje hitrosti burje od dinarske pregrade proti obali oziroma od Podgorskega krasa proti morju, je razvidno tudi iz terenskih meritev na najbolj izpostavljenih predelih ob močni burji 21.1.1993, med 15:40 in 17:10, ko je burja relativno enakomerno pihala. Tedaj so v Ajdovščini namerili sunke do $45 \mathrm{~m} / \mathrm{s}(162 \mathrm{~km} / \mathrm{h})$, na Kozinskem in Petrinjskem krasu je pokazal anemometer 31 do $38 \mathrm{~m} / \mathrm{s}$, pri Stepanih pod Tinjanom nasproti Kraškemu robu $25 \mathrm{~m} / \mathrm{s}$, na izolski Punti in na Belem križu ob morju pa od 24 do $28 \mathrm{~m} / \mathrm{s}$. Hitrost burje je na izpostavljenih predelih ob morju precejšnja (na to so nas opozarjale tudi deformirane krošnje), ker nad morjem ni velikega trenja, ki bi zmanjšalo hitrost. Horizontalni gradient zmanjšanja hitrosti burje med Kozino in izolsko Punto je znašal $0,4 \mathrm{~m} / \mathrm{s}$ na $1 \mathrm{~km}$, med Ajdovščino in Izolo pa skoraj $0,5 \mathrm{~m} / \mathrm{s}$ na $1 \mathrm{~km}$.

V bolj zatišnih legah, npr. v Rižanski dolini in v Portorožu, so sunki burje dosegali hitrosti od 5 do $14 \mathrm{~m} / \mathrm{s}$. V Rižanski dolini je drugod prevladujoča SV smer burje povzemala tudi smer doline. Zanimive so bile razmere v Zgornjem Črnem kalu, ki leži skupaj z ostalimi vasmi v Bržaniji v relativnem zatišju pred burjo. Vetru smo tu izmerili najmočnejši sunek $7 \mathrm{~m} / \mathrm{s}$, vendar to ni bila burja, ampak veter z zahoda do SZ, to je iz smeri Tinjana. Ob prehodu močnejše burje čez Kraški rob očitno prihaja tudi tu 
do vrtinčenja. To nam potrjujejo tudi meritve naslednjega dne, ko je burja oslabela in vrtinčenja ni bilo več. Tudi v Črnem kalu je imela burja SV smer, njena hitrost pa je za okoli $10 \mathrm{~m} / \mathrm{s}$ zaostajala za hitrostjo na Podgorskem krasu.

Slika 4: Hitrost burje na profilu od Petrinjskega krasa do morja (21.1.1992; 15:40 - 16:50)

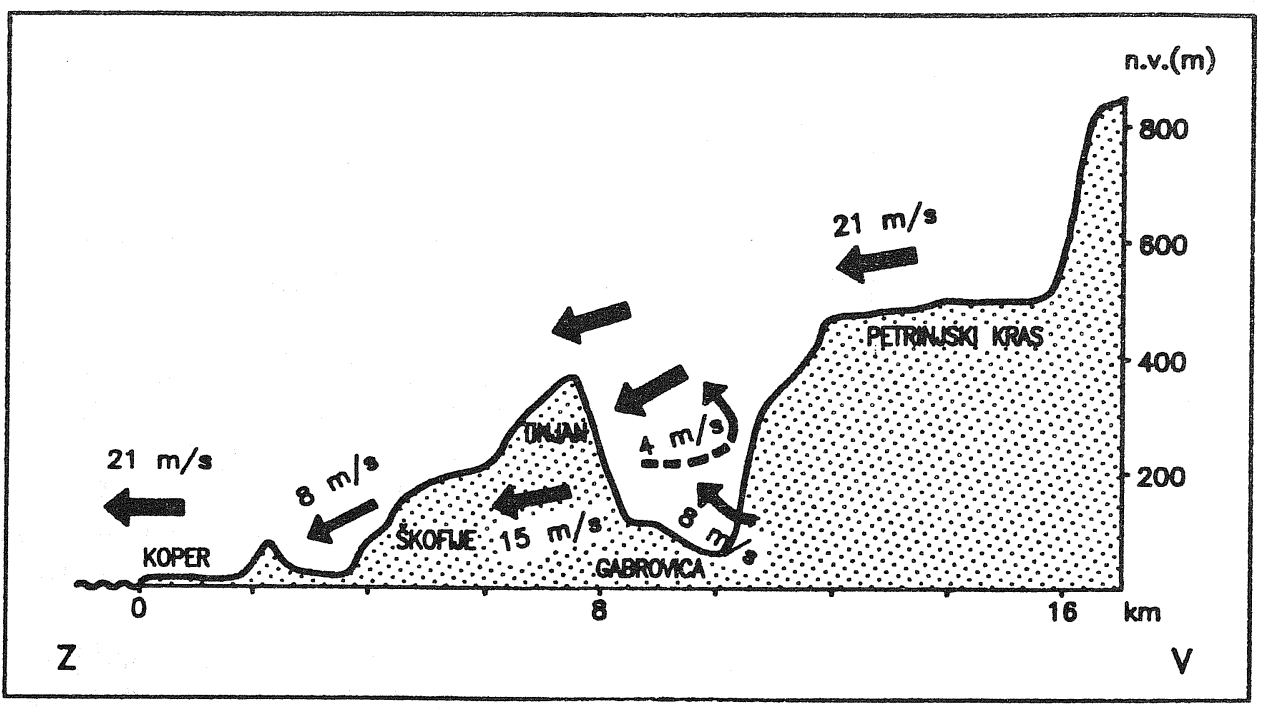

\section{SKLEP}

Vloga reliefa kot modifikatorja klimatskih razmer na mezo ravni je v Sloveniji relativno dobro poznana. Tovrstne študije se naslanjajo predvsem na uporabo podatkov meteoroloških postaj. Obstoječa mreža meteoroloških opazovalnic pa običajno ne zadošča za študij lokalnih in mikrorazmer, ker je preredka oziroma je Slovenija reliefno prepestra. Prav poznavanje lokalnih klimatskih razmer pa je z vidika različnih sfer življenja, med drugim tudi $\mathrm{z}$ vidika vojaške stroke, velikega pomena. Za tovrstna spoznanja je potrebno opravljati dodatne klimatske terenske meritve in opazovanja, ki so zanesljivejša, če potekajo dlje časa, kar pa vedno iz različnih vzrokov ni mogoče.

$\mathrm{V}$ določenih primerih pa si lahko pri analizi lokalnih in mikroklimatskih razmer pomagamo s posrednimi metodami. Med te sodita tudi ugotavljanje pogostosti in intenzivnosti inverzije s pomočjo vegetacijskih razmer in značilnosti v kulturni izrabi pokrajine (razprostranjenost termofilnih vegetacijskih združb, rastišča klimatsko zahtevnejših kulturnih rastlin, pojav vegetacijskega obrata, fenološki ritmi) ter ugotavljanje območij, ki so bolj ali manj izpostavljeni burji s pomočjo deformiranosti drevesnih krošenj, kar smo med drugim skušali tudi prikazati v prispevku. Pri tovrstnih raziskovanjih pa velja biti v določeni meri previden, ker so klimatske razmere le eden od dejavnikov okolja, ki vpliva na rast. Kljub morebitni dominantnosti klime pa je nujno potrebno, z vidika korektnega ovrednotenja njenega vpliva, poznavanje celotnega sistema biotskih in abiotskih dejavnikov, ki vplivajo na rastne razmere $v$ določenem okolju. 


\section{VIRI IN LITERATURA}

- Arhiv HMZ RS: Klimatski podatki za meteorološki postaji Portorož -Beli križ in Portorožletališče za obdobje 1987-1992, Ljubljana.

- Barsch D., 1963: Wind, Baumform und Landschaft, Freiburger Geogr. Hefte 1, Freiburg, str.21130.

- Beck L., 1906: Die Umkehrung der Pflanzenregionen in der Dolinen der Karstes, Sitzungsber. Akad. Wiss., Bd.115 (1-10), Dunaj, str. 3-19.

- Dakskobler I., 1996: Združba Seslerio autumnalis - Fagetum (Ht.) M.Wraber ex Borhidi 1963 v Koprskem primorju, Annales 9/1996, ZDJP in ZRS RS v Kopru, Koper, str. 181-200.

- Gabrovec M., 1996: Solar Radiation and Diverse Relief of Slovenia, Geografski zbornik 34 (1996), GIAM ZRC SAZU, Ljubljana, str.47-68.

- Gams I., 1996: Termalni pas v Sloveniji, Geografski vestnik 68 (1996), ZGDS, Ljubljana, str. 538.

- Gams I., Mihevc A., 1978: Nova odkritja v Ledeni jami v Paradani, Naše jame 20 (1978), Ljubljana, str. 7-20.

- Gams I., 1972: Prispevek k klimatogeografski delitvi Slovenije, Geografski obzornik 19 (1972), št.1, ZGDS, Ljubljana, str. 1-9.

- Kavčič I., 1996: Vetrovno preoblikovana drevesa na Trnovskem gozdu, Geografski obzornik 43 (1996), št.2, ZGDS, Ljubljana, str. 20-26.

- Martinčič A., 1977: Prispevek k poznavanju ekologije mrazišč v Sloveniji, Razprave IV. Razreda SAZU, Ljubljana, 91 str.

- Ogrin D., 1996: Podnebni tipi v Sloveniji, Geografski vestnik 68 (1996), ZGDS, Ljubljana, str.39-56.

- Ogrin D., 1995: Podnebje Slovenske Istre, Knjižnica Annales 11, ZDJP, Koper, 381 str.

- Petkovšek Z., 1965: Regionalni vremenski tipi v Sloveniji v letih 1957-1958, Razprave V, DMS, Ljubljana, str. 59-104.

- Yoshino M.M., 1976: Local Wind Bora, University of Tokyo Press, Tokio, 289 str.

- Yoshino M., Yoshimura M., Mitsui K., Yoshino M.T., Oswada M., Ueda S., Urushibara K., Nakamura K., 1976: Local Observations Made in the Ajdovščina Regio of Slovenia, v: Yoshino M.M.: Local Wind Bora, Tokio, str. 41-58.

- Temperaturni obrat v hriboviti Sloveniji, Dela 13 (Sonaravni razvoj v Slovenskih Alpah in sosedstvu), Odd. za geografijo FF, Ljubljana, str. 237-248.

- Vpliv klime na lego in razširjenost vinogradov na primeru srednjih Slovenskih goric, Geografski zbornik 32 (1992), GIAM ZRC SAZU, Ljubljana, str. 50-139.

\section{SUMMARY}

The landforms of Slovenia are of the above-average importance for its weather and climatic characteristics, which particularly refers to the course of mountain barriers, the altitude structures, exposure and inclination of slopes, and the type of surface. Concave landforms are very important for the distribution of minimum temperatures in anticyclonic weather conditions which have about 50\%-occurence. If the radiation balance between the radiation of surface and the reradiation of atmosphere is negative, temperature inversion occurs in the concave landforms where the accumulations of cold air are formed, which is visible in the form of fog layer. Favourable conditions for this phenomenon occur in all the basins (the Ljubljana-, Celje-, Slovenj Gradec- basins), valleys (the Mura-, Drava-, Krka valleys) and karst poljes (the Pivško-, Cerkniško-, Ribniško-Kočevsko poljes). Thus, the average temperatures in inversion areas are lower by $1^{\circ} \mathrm{C}$, and the minimum temperatures are lower 
by $2-3^{\circ} \mathrm{C}$ than the temperatures in the higher-lying thermal belt. The latter begins at $15-30$ $\mathrm{m}$ above the valley bottoms and reaches up to $400(450) \mathrm{m}$ of relative height. It is favourable for growing certain climatically more demanding cultures (grapevine in the subpannonian Slovenia, olive tree in the submediterranean Slovenia).

The actual differences in minimum temperatures between the areas of inversion and the thermal belt are even greater. According to an investigation performed in Slovenian Istria, where the mediterranean climate mainly prevails, these differences amount to $1-4^{\circ} \mathrm{C}$ in the littoral belt, and $4-8^{\circ} \mathrm{C}$ in the inland area where the inversion is more explicit. Outstanding by strong inversions are the fluvioglacial valley systems on the contact of the karstic and the flysch parts of Slovenian Istria. Very favourable conditions for the formation of inversion also occur in the karst depressions and in the high Dinaric plateaus in Slovenia. On the bottoms of some of these depressions, or at the entrance to the cave into which the depression continues, snow and ice remain yearlong owing to the shady position, and the temperature inversion continues irrespective of the weather type. Thus, at Paradana on the Trnovski gozd plateau $(1100 \mathrm{~m})$, there is an area of constant temperature inversion (mrazišče) at the entrance to the Velika ledena jama (The Great Ice Cave), about $90 \mathrm{~m}$ deep, where inversion of vegetation also occurs as a result of temperature inversion. At the bottom, where the temperatures are below $0^{\circ} \mathrm{C}$ in the cold half of the year, and constantly between 1 and $3^{\circ} \mathrm{C}$ in the warmer season, moss only grows. Higher up grow alpine herbs which are followed by subalpine bushes; in normal conditions, the latter occur 600-800 m higher. Then follows a belt of an alpine willow type, salix grandifolia, next comes spruce, and on the upper rim of the mrazišče grows the Dinaric fir-and-beech forest.

Due to the flow of cooler continetnal air to the littoral area across the high Dinaric plateaus, bora is typical of the areas lying south and southwest of the above-mentioned barrier. Its frequency and high velocities provide a special feature to the littoral areas. Besides its numerous effects, bora also causes deformities in the growth of trees, or the so-called wind-shaped trees, by means of which some of its geographical characteristics can be investigated. It is typical of Slovenian Istria, studied on the profile running from Mt. Sinji vrh on the Trnovski gozd to the sea, that the bora is the strongest at the edge of the Trnovski gozd and direcly below it, in the Vipavska dolina valley; then, it decreases towards the sea. It reaches the highest velocities on the open landforms and at the vertical drops where turbulences occur, as well as on the exposed capes in the sea. Prevailingly, bora is the NE wind, although its direction varies quite significantly owing to the landforms' channelling. According to the Barsch list of trees' deformities, bora decreases from the Trnovski gozd to the Podgorski kras (the karst of Podgorje), here being the most explicit in Slovenian Istria, with degrees 1-2. According to the measurements performed, its velocity decreases by $0.4-0.5 \mathrm{~m} / \mathrm{sec} / \mathrm{km}$. 